\title{
Innovation on ideological and political education method in new media time
}

\author{
Li Yang \\ Digital Art Institute, Xi’an University of Posts \& Telecommunications, Xi'an Shanxi, 710121, China
}

Keywords: New media, Ideological and political, Education, Innovation.

\begin{abstract}
. the uprising of new media time has promoted the formation of ideology and politics, political and moral thought and ideological value, as well as new developmental chance and challenge for the ideological and political education at present. This article forms a general understanding on new media, analyzes advantages of ideological and political education application in new media time and some practical problems existing in current development, and finally explains some innovative methods in ideological and political education in new media time.
\end{abstract}

\section{Introduction}

New media time has highlighted the main features of information spreading not only with rich and diversified information contents but also with high values of information and searching forms of information. The continuous development of new media technology has provided great convenience for people to obtain information and impacted people"s ideological and political education. Under the developmental form of new media time, its application to ideological and political education can help to form new ideological and political concept.

\section{Introduction of new media}

Unlike newspaper, broadcast, TV and other traditional media, it is formed mainly with network media such as Smartphone, micro blog, and digital TV to send information to terminal media through network technology and internet so as to provide better service for people. The uprising of new media has promoted people"s life and thinking method, optimized traditional production and living mode, and applied in commercial, education and cultural domain so as to construct a carrier format for information transmission for the social development for the convenience of people"s good communication. Meanwhile, new media has been well received and loved by students so that it has changed their thinking modes and values to some degree. It has also proposed new challenges and good developmental chances for the ideological and political education in colleges and universities.

\section{Advantages of application of ideological and political education in new media time}

There is a special educational advantage during the application of new media into ideological and political education. Since new media is a tool of knowledge spreading and information communication to provide reasonable transmission carrier for ideological and political education in colleges playing an advantageous role. Firstly, new media is with huge authority as its positive development can not only help the promotion and inheritance of traditional media but can also provide important theoretical promotion domain for China and relevant governments. Therefore it plays an important role in ideological and political education promotion work. Secondly, new media has coverage as its spreading objects are the public and the society so that it has wide and strong coverage. Using different forms of new media and promoting the positive application between each 
other can prevent being limited from time and space so that people can realize the real-time sharing of relevant information. The features of new media coverage accord with college students" age, characters and life habits and new media becomes an important promotion carrier for the ideological and political education form in colleges. Thirdly, new media has advanced characteristics as its main advantage is to expand the public spreading influence and promote the quickness, diversification and promptness of the information acceptance so as to achieve its good transmission effect and endow the time with the changing requirement. Application of new media into colleges, college students will be more willing to try new things and new experience brought by new technologies. Thus new media has played its own potential advantage in college ideological and political education.

\section{Realistic problems existing in the ideological and political education development in new media time}

\section{current development characteristics}

Under the development in new media time, characteristics of college ideological and political education are mainly reflected in some aspects within the whole country. First is the current situation of students using new media. In colleges, the main ways which students use new media are computer or Smartphone, which are the primary tools in their study and lives. Among all media such as newspaper, TV, cell phone, and computers, most students would use cell phone and internet as the main transmission media. According the actual change in the development, normally, college students will spend two or more hours on the internet mainly for the purpose of entertainment and few students use new media for study. Second is the college students" awareness of new media. Most college students would think that new media has been widely and easily applied which can make their life and study richer and more convenient so that colleges students would love to use new media in their life and study. In this cognition, although new media has its own openness and equality to provide a free space during its application so that students can boldly speak out their own ideas and opinions. But most students have not formed a correct awareness of new media. They do not have a full understanding of information transmission and they have no rational judging ability for information from new media. Thus students" ideological awareness has been influence greatly by new media on perception of new media and values. Third is the college ideological and political education application and the acceptance situation for new media. New media has features of high efficiency and quickness which is widely used in education, management and ideological and political education. College students use new media mainly through groups or social media for information communication to use internet to communicate with ideological and political education workers. But regarding this method, students are more willing to use diversified transmission methods during ideological and political education activities so as to promote the new media to be fully used.

\section{Some prominent problems in the education}

In new media time, there are a lot of problems in ideological and political education in colleges. In the development phase of new time, college students have started contacting new media and have owned the basic qualities to use new media so that the application of new media in college ideological and political education can provide convenience. But on the other hand, there are some problems during the application. Firstly, the main body of college ideological and political education lack media quality, so college students and college ideological and political education workers should improve their ability to use new media such as ability of judgment and recognition capability. Secondly, main contents of college ideological and political education can still no satisfy the development requirement of modern new media [2]. With the popularization and application of new media technology, relevant scholars should learn more valuable information knowledge and provide rich teaching resources for colleges to broaden students" horizon. Thirdly, college ideological and political education methods are still left behind, and colleges still use traditional methods ways. They 
just simply copy the teaching pattern simply to form a new media form. Under this kind of teaching form, it is hard to integrate new media into college ideological and political education work, and hard to carry out colorful and flexible college ideological and political education activities. Fourthly, college ideological and political education activities show complicated and diversified features. As new media time is a time of diversified developmental form when people"s traditional ideological concepts are being shocked, which influence the formation of national and social ideology and also present its complication with the gradual change of students" ideological formality. Therefore, under the construction method of advanced ideology, information mainstream broadcasting and harmonious culture, college ideological and political education is faced up to challenges.

\section{Innovation on ideological and political education method in new media time}

\section{develop the method of subject education}

When using new media to develop college ideological and political education subject, firstly, college should positively improve students" media literacy. Media literacy is an education form in students" class study which can positively guide students" ideology and promote the ideological and political education activities to be carried out. Therefore, pay attention to the excavation and positive cultivation of leaders and help students make full use of their subjectivity. During the process of information spreading, choose outstanding students to supervise and intensify their subject consciousness but also should improve their own political accomplishment and their own responsibility so as to achieve students" self-discipline in the spatial range of new media. Then cultivate students" expertise in ideological and political education. With the main ideology of ideological and political education in its modern development as the guidance concept, make each student fully realize the great ideal brought by new media in the new media time and make them positively learn relevant broadcasting knowledge so as to master information transmission techniques and methods so as to use new media to promote better spreading based on the development rules of ideological and political education in colleges. Finally, realize the supplementary and combination of new media"s advantages and disadvantages [3]. Firstly, know each feature of new media such as the real-time communication of IM including QQ, MSN and other apps people use. These can promote the good communication and fast spreading of college ideological and political education. For example, Email has the main function of quick location so that its application in college ideological and political education can be of pertinence and accuracy. Regarding SNS which is public communication software can promote the equal and interactive development between objects and subjects during the promotion of college ideological and political education. Regarding blog which has its individual and self-disciplined development can help students form a self-teaching accomplishment during the cultivation of students" ideological and political education. For Microblog which is a widely use app can realize the purpose of real-time transmission and subscription and can help to effectively command the information updates during the promotion of ideological and political education in colleges. Therefore, using education subject and making full use of advantages and disadvantages of new media can have a great interactive function.

\section{Make full use of educational channels}

Use new media to promote the innovative development of college ideological and political education, firstly positively expand educational channels of college ideological and political education. Promote the class effect of college ideological and political education theoretical class teaching and use new media to promote some refined teaching methods such as broadcasting teaching and live broadcasting teaching so as to form a teaching form integrating characters, sounds and images. Then put ideological and political teaching theories into practice so as to strengthen the infectivity of this kind of teaching form so as to create a bi-directional teaching mode for the theoretical development of ideological and political education. Secondly, provide new developmental base for college ideological and political education and establish a network dredge mechanism based on the media 
forms in colleges. Meanwhile, pay attention to students" developmental updates timely and interact with students with reasonable ideological culture to develop the area into the main base. Also, regarding the construction of campus network, cultivate a group of professional new media supervisory staffs including student unions in colleges, student cadres, instructors and campus media managers. Each module should promote the activity of campus media but also should make correct guidance with healthy consensus [4]. At last, try best to perform college ideological and political education work well. Based on the practical situation of college students" study, establish QQ group, Wechat group, and blog group for students to establish a platform for information interactive communication. In this way, students can exchange their experiences but can also share different feelings in their lives and know some popular social and political events and hot points at present so that they can devote themselves into college ideological and political education work with passion and enthusiasm.

\section{Educational strategies to achieve innovation}

Use new media to promote the innovative development of ideological and political education, main strategies to be implemented includes: firstly, with the college"s " red site" as main-part construction, establish some forms suitable and favorable for students according primary forms of the website construction [5]. Carefully design the teaching contents, keep expanding the promotion region of new media, and vigorously develop relevant software of ideological and political education so as to improve the advancement of this teaching form. Secondly, achieve the method of combining interior and exterior network,, and find out the chance and starting point when reasonably choosing the ideological and political education base. Based on the basic condition of network ideological and political education, promote the integrated development of inner campus and off-campus not only by all people"s participation but also to take real-time supervision. This method is to effectively combine new media with traditional media and use the potential advantages in traditional media to enrich the information usage forms of new media. Thirdly, with some acceptable contents as the research strategies, make analysis on students" mental change and potential requirements and choose educational methods specifically so as to satisfy students" developmental demands. During the selection of teaching contents, follow features of pertinence, flexibility and authenticity. In this way college ideological and political education work can achieve good effects.

\section{Conclusion}

Ideological and political educational development has presented the educational essence of socialism and the application of new media is the primary requirement to develop socialist cause with Chinese characteristics and is to provide new developmental force for the national rejuvenation of China. New media as a tool can help to promote and explain relevant theories of Ideological and politics but can also help construct the systematic development to cultivate talents suitable for Chinese socialism based on the demands of the development of the ages.

\section{Reference}

[1] Ji Haiju. Study on college ideological and political education in new media time, Nanjing Normal University,2013.

[2] Xu Hui, Zheng Fangmin, Yu Xingye. Thinking and practice on college ideological and political education method innovation, Heilongjiang Researches on Higher Education,2014(12):135-136.

[3] Zhao Yang. Creative thinking on college students" ideological and political education workv under new media background, Studies in Ideological Education, 2011(12):72-74. 
[4] Yan Jing, Liu Zhuo. Strategic innovation in higher vocational college students" ideological and political education under the vision of new media, Oriental Enterprise Culture,2015(19):167-167.

[5] Yang Ruwei. Some thoughts on innovating college ideological and political education methods in new media environment, Learning Weekly (Edition A),2014(11):12-13. 